\title{
Analyzing the Level of Information Literacy Skills of Medical Undergraduate of Eastern University, Sri Lanka
}

S. Santharooban ${ }^{1}$

\begin{abstract}
The study was executed to analyze the level of Information Literacy skills of medical undergraduates of Eastern University, Sri Lanka, who are engaged in Problem Based Learning (PBL). As the information literacy (IL) skills are the core elements of independent self-directed learning, the PBL must be coupled with IL skills to achieve the maximum benefit of the PBL. The study used the cross sectional survey which used Information Literacy Quiz as an instrument. IL quiz consists of multiple choice questions related to different array of IL skills. Students' samples were selected randomly and the sample size was 85 . The results revealed that the overall average for the IL competency level of medical students is $39 \%$, which ranges from $13.57 \%$ to $65.71 \%$, and about $43 \%$ of students fall within the 'Satisfactory level' (41-60\%). When considering average for each skill, analytical skill is $31.36 \%$, locating skill is $47 \%$, comprehension and creating skill are $26.36 \%$ and presentation skills is $51.14 \%$. There was no statistical significance in the level of IL skills between genders and there is no association between gender and the level of different IL skills. Furthermore, the study reveals that students do not have sufficient knowledge in concept mapping, $5 \mathrm{Wh}$ technique, effective reading methods, note taking techniques, search strategies, use of library catalogues, evaluation of website, and structuring report, and plagiarism. They also do not know the difference between databases and search engines, and scholarly work and nonscholarly work. The study, at the end, suggests that it is essential to improve the IL skills among the students before they are engaged in PBL.
\end{abstract}

Keywords: Information Literacy, Problem-Based Learning, Information overload, ACRL standard.

\footnotetext{
${ }^{1}$ Senior Assistant Librarian, Faculty of Health-Care Sciences, Eastern University, Sri Lanka. Email:santharoobans@esn.ac.lk
} 


\section{Introduction}

Since the higher education system is designed based on adult learning concept, the students take major part in learning while the teachers take the facilitator's role, unlike the secondary school education. The students' role as a learner involves the independent learning, which will lead them to become a lifelong learner in future, as long as the core of lifelong learning is the independent learning (Bundy, 2004). Lifelong learning is "the process of constant learning and development that incorporates continuous professional development, in which all individuals need to engage in a time of rapid change" (WCPT, 2003). To achieve ultimate goal of making students as lifelong learner, the students have to be trained in independent learning and self-directed learning.

Presently, technological era supports the students who are intended to engage in independent learning by creating number of choices of information resources, especially in different digital formats. These information resources make them to learn independently irrespective of their conventional learning spaces such as classroom and libraries. Meanwhile, the overwhelming amount of information resources presents a challenge to students by creating an environment with information overload.

The information overload, derived as result of rapid technological development in the field of information and communication technology and in publication business, highly pressurize the academic and research activities. It has been reported that the annual information production is about 1 to 2 Exabyte (Jungwirth \& Bertram, 2002). It is common to every field, nevertheless, Haraldstad (2002) reported information explosion exert highest pressure in the field of medicine. Haraldstad (2002) further adds that annually more than 2 million articles are being published in about 21,000 biomedical journals, and these figures are increasing with the trend of $4 \%$ each year. The information overload not only pressurizes the academic and research activities but also create ambiguity in the authenticity, validity and reliability of the published information.

Since there are number of resources in the information overloaded 
environment, mere presence of information will not help to develop the knowledge. Laurillard (n.d) compares the information as bricks and knowledge as the building as follows:

"...information is to knowledge as bricks are to buildings. It is as absurd to try and solve the problems of education by giving people access to information as it would be to solve the housing problem by giving people access to bricks. Part of the point of an education is to give people the skills and understanding to enable them to handle information."

Therefore, to cope up with independent learning in an information overloaded environment, it is inevitable for the students in higher education system to be information-literate to develop set of abilities to extract the appropriate information from the sea of information in the shortest possible time, and to critically evaluate the authenticity, validity and accuracy of the information. These sets of abilities needed for the information seeker is known as 'Information Literacy' (IL). According to the ALA (1989) information literacy is "the ability to locate, evaluate, and use information to become independent, lifelong learners." If the students lack in the skills needed to find and use information effectively, they can be burdened by information overload (Andretta, 2005). As the independent learning is the core of the lifelong learning, information literacy is also the core of independent learning (Bundy, 2004). Hence, the training on information literacy plays a pivotal role in the development of independent learner in academic environment (Peters et al., 2007), and is one of the topic which has been discussed in academic arena worldwide.

The universities in Sri Lanka are progressively introducing the IL at undergraduate level by the effort of respective librarians. When developing an IL programme, students cannot be considered as black boxes that they do not have any skills of IL. The students can have developed the IL skills to some extent with their cognitive ability and their experience. Hence, it is essential to study the initial level of IL of the students, so that the information literacy programme could be designed to identify and overcome the areas of weaknesses in the IL skills of students (Thirion \& Pochet, 2009). 
There are several assessment of IL skills among students around the world, but in Sri Lanka there are only a few studies carried out. The study by Seneviratne \& Wickramasinghe (2010) is one such study which analyzed the IL skills of undergraduate of University of Moratuwa.

This paper elaborates on the findings of such assessment conducted at Faculty of Health-Care Sciences, Eastern University, Sri Lanka. The faculty has Problem-Based Learning (PBL) in its curriculum. In PBL, students are presented with triggers or problems which have been formulated based on real case histories and they work in teams through a structured process to solve and acquire the background knowledge about a particular problem. Since the independent and self-directed learning is the heart of the PBL process, there is a strong necessity for IL for the students who are engaged in $\mathrm{PBL}$, as the information overload pressurize the problem based learning process. There are eight steps in the faculty PBL process which are a) introduction of trigger; b) identification of keywords, c) brainstorming, d) identification of learning needs, e) discussion, f) self-directed learning, g) presentation, and $\mathrm{h}$ ) review, which are repeated in circular process (Santharooban \& Premadasa, 2015). All these steps needs some array of information skills that are Analytical skills, Locating Skills, Comprehension Skills, Creating Skills, Presenting Skills, and Evaluating Skills. If the students are not trained in those skills, he/she cannot perform well in PBL. Oker-Blom (1998) states that "information skills are perceived as core skills for effective independent learning in PBL." Rankin (1992) also states that "information-seeking skills are central to the PBL curriculum, which emphasizes self-directed learning and the acquisition of problem-solving and lifelong learning skills".

In a study carried by Dodd (2007) on the impact of problem-based learning in the information seeking behaviour and information literacy of Veterinary Medicine Students at University College Dublin, the students reported that they faced problems when seeking information for PBL because of information and resource overload. Since information literacy is important to PBL, universities such as University College Dublin, Ireland (Dodd, 2010), School of Medicine, University of Pittsburgh (Schilling et al., 1995) have an 
integrated information literacy programme with Problem Based Learning. Therefore, the students especially who engaging in PBL should be trained in IL skills.

In this regard, the study aimed to analyse the level of IL skills of the students at Faculty of Health-Care Sciences, Eastern University, Sri Lanka, who are engaged in PBL.

\section{Methodology}

A cross-sectional study was conducted among the medical undergraduate of Faculty of Health-Care Sciences of Eastern University, Sri Lanka. The target population was the medical undergraduates from second year to final year. The sample size for this study is 85 (according to the Bartlett et al., 2001). Students were selected as samples using simple random sampling method.

The study used Information Literacy Quiz as research instrument. The information literacy quiz, consists multiple choice questions (MCQ), is now widely used by researchers and universities to assess the information literacy skills among students. Ivanitskaya (2006) used the information literacy MCQs in Research Readiness Self-Assessment (RRSA), which was used to do the survey online. In addition, Mittermeyer and Quirion (2003), Trail et al. (2006), Staley et al. (2010), Seneviratne \& Wickramasinghe (2010) and an IL assessment report of Millikin University (Campbell, 2009) have also used the information literacy MCQs to assess the information literacy.

In the same way, the information literacy quiz has been used in the present study. The quiz begins with a model PBL trigger and consists of a number of multiple choice questions related to information literacy skills, except the first question, which is open-ended to identify the keywords from the trigger. The questions have been designed to test specific information literacy skills needed for PBL and mostly the questions were obtained from the above mentioned research. There are nineteen multiple choice questions in the quiz. The questions 1-5 have been designed to test 'analytical skills', 6-12 for 'Locating skills', 13-14 for 'comprehension skills', 15-17 for 'creating skills' and 18-19 for 'presentation skills.' Each multiple choice question's answers consist "I don't know" as last choice. In addition, demographic information 
such as details of semester, gender and age were obtained at the beginning of the quiz. The quiz was administrated among students and the data were collected.

\section{Analysis of Information Literacy Quiz}

In the Information Literacy Quiz, numbers of responses for each choice for nineteen multiple choice questions were recorded and it has been converted to percentages. The responses for each choice were represented in percentage and presented in table for each question.

In addition, the multiple choice questions were grouped into different skills such as analytical skills, locating skills, comprehension skills, creating skills and presenting skills. Each skill was scored to hundred for every respondent and average mark for particular skill was calculated from the marks of all the respondents. The marks were grouped into five levels which are 'Very Poor' for $0-20 \%$, 'Poor' for $21-40 \%$, 'Satisfactory' for $41-60 \%$, 'Good' for $61-80 \%$ and 'Excellent' for $81-100 \%$ and the percentage of respondents who falls under each group were graphed. Finally, average marks for the whole information literacy quiz was scored.

\section{Results and Discussion}

\section{Analytical Skills}

The standard of ACRL (2000) and standard developed by Australian and New Zealand Information Literacy Framework (Bundy, 2004) have mentioned that "Recognizing the need for information and determining the nature and extent of the information needed" is the first information literacy standard. In order to achieve this standard, a person must have some array of skills, which can be collectively called as analytical skill. The analytical skill is the first step in any IL model and through which the need for the information or gap on information has been analysed according to the situation. Under the analytical skill, the students must have the ability to identify the keywords and to establish the links between the keywords and key concepts in relation to their previous knowledge on the particular subject. Furthermore, one of the performance indicators under the first standard of ACRL (2000) is "the information literate student identifies a 
variety of types and formats of potential sources for information." Therefore, the students must have to identify the appropriate sources of information, under the analytical skill.

As such, the multiple choice questions number 1-5 in the information literacy quiz have been designed to test the abilities to identify keywords (question number 1), to use of concept mapping and $5 \mathrm{WH}$ technique (question numbers $2 \& 3$ ) and to identify the sources of information (question numbers $4 \& 5$ ). As the study analyses the IL skill s of students who are engaged in the PBL, the questions start with a model PBL trigger, as follows:

In a Problem Based Learning class, you are provided with following trigger. Mr. Anthony, 57 years old, Bank Manager, came to the emergency unit with severe sweating and pressing his chest with his right hand. On inquiry, he told that 'I am having severe chest pain for the last 2 hours. It feels like someone squeezing inside'. 'I also vomited several times in the last 2 hours'.

Question 1: "Write at least five keywords from the above trigger"

Among the respondents, $66 \%$ of students identified keywords without errors, while the rest of them selected erroneous keywords. Among them about 70\% of them selected the 'Mr' and 'Mr. Anthony' as keywords. Moreover, most of the students have written the sentences instead of the keywords.

The questions numbers 2 and 3 have a stem as follows:

"Your PBL tutor instructs your group to use the 'Concept Map' and '5WH technique' to analyze the problem"

\begin{tabular}{|c|c|}
\hline \multicolumn{2}{|l|}{ Question 2: } \\
\hline What is concept map? & $\begin{array}{l}\% \text { of } \\
\text { students }\end{array}$ \\
\hline a. geographical locations of hard to find places & 0 \\
\hline b. ways to graphically represent information in trigger & 9 \\
\hline $\begin{array}{l}\text { c. a system of linking key points in trigger with prior } \\
\text { knowledge }\end{array}$ & 41 \\
\hline d. All of above & 5 \\
\hline e. I don't know & 45 \\
\hline
\end{tabular}


Among the respondents, only $41 \%$ of students have selected appropriate answer (answer c), while $45 \%$ of students admitted that they did not know about concept map and the rest of them have selected the wrong answer.

\begin{tabular}{|l|c|}
\hline \multicolumn{2}{|l|}{ Question 3: } \\
\hline What is 5WH technique? & $\begin{array}{l}\text { \% of } \\
\text { students }\end{array}$ \\
\hline a. It is a way of 'getting into' a trigger & 2 \\
\hline b. It assists to find out what aspects of the topic that \\
$\quad$ you need to study & 5 \\
\hline c. What, where, who, when, why & 30 \\
\hline d. All of above & 9 \\
\hline e. I don't know & 55 \\
\hline
\end{tabular}

The appropriate answer (answer d) for the question was selected by only $9 \%$ of students while $55 \%$ of students admitted that they do not know the answer, and the rest selected the wrong answer.

\begin{tabular}{|c|c|}
\hline Question 4: \\
\hline $\begin{array}{l}\text { At the end of the discussion, you identify "infarction" is } \\
\text { one of the learning needs. Which one of the following } \\
\text { resource is best to quickly get the basic background } \\
\text { information about the term infarction? }\end{array}$ & $\begin{array}{l}\text { \% of } \\
\text { students }\end{array}$ \\
\hline a. Journals & 0 \\
\hline b. Medical Encyclopaedia & 20 \\
\hline c. Books & 59 \\
\hline d. Dictionary & 5 \\
\hline e. PBL tutor & 11 \\
\hline f. I don't know & 5 \\
\hline
\end{tabular}

Most of the respondents (59\%) have selected the 'Books'. However, only $20 \%$ of respondents selected the appropriate answer (Medical Encyclopaedia). Some of the students (11\%) have selected 'PBL tutor' as a source to get basic and background information.

\begin{tabular}{|l|c|}
\hline Question 5: & \multicolumn{2}{|c|}{} \\
\hline Which of the following is a database? & \% of students \\
\hline a. Google & 50 \\
\hline b. Altavista & 0 \\
\hline c. PubMed & 20 \\
\hline d. Dogpile & 0 \\
\hline
\end{tabular}




\begin{tabular}{|c|c|}
\hline The Lancet & 5 \\
\hline f. I don't know & 25 \\
\hline
\end{tabular}

Fifty percentages of the respondents have selected 'Google' as database, while $25 \%$ of the respondents admitted that they do not know. However, only $20 \%$ of the respondents have selected the appropriate answer (PubMed).

These five questions were given with marks to assess the overall score of analytical skill. The distribution of marks in the marks group is shown in Figure 1. The overall average score for analytical skill is $31.36 \%$ out of hundred percentages. The overall average for female is $30.4 \%$ and for males $32.6 \%$, but there is no statistical significance between male and female ( $\mathrm{p}>0.05)$. However most of the students' (52\%) marks fall under the 'Very Poor' level (i.e. $0-20 \%$ marks group). Further, there is no association between gender and level satisfaction at $95 \%$ confident interval (Chi square 4.157, df-2, p-0.125).

The students have difficulties in identifying the appropriate sources of information. Most of the students did not know the clear difference between search engines and databases. Moreover, the students do not have knowledge on the use of medical encyclopaedias. However, it has been noted that there are ample amount medical encyclopaedias in the faculty library. Further, the results also reflect that students did not have enough idea on concept maps and $5 \mathrm{WH}$ techniques.

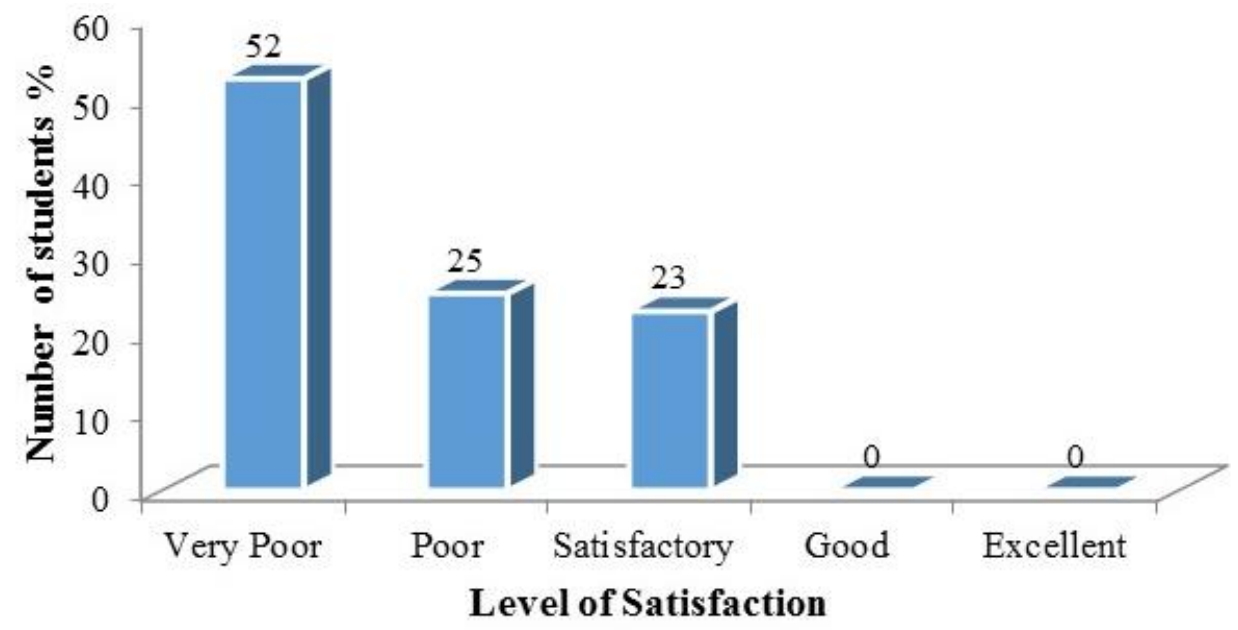

Figure 1: Distribution of analytical skill marks 


\section{Locating Skills}

In the information literacy quiz, the multiple choice questions numbers 6 to 12 test different skills under the locating skill.

The second information literacy standard of ACRL (2000) is "The information literate student accesses needed information effectively and efficiently." Under this standard ACRL (2000) further defined some performance indicators such as selecting appropriate investigative methods or information retrieval systems, constructs and implements effectivelydesigned search strategies and retrieves information online or in person using a variety of methods. The questions numbers 6 to 10 in the information literacy quiz have been designed to test the students' ability based on the above mentioned performance indicators.

A performance indicator of ACRL (2000) under the standard three states that "the information literate student articulates and applies initial criteria for evaluating both the information and its sources". The questions numbers 11 and 12 have been designed based on this performance indicator.

\begin{tabular}{|c|c|}
\hline \multicolumn{2}{|l|}{ Question 6: } \\
\hline $\begin{array}{l}\text { You are visiting a well-established library to find a particular } \\
\text { book. But the library is unfamiliar to you. Which one of the } \\
\text { following is most appropriate to locate the book you need. }\end{array}$ & $\begin{array}{l}\% \text { of } \\
\text { students }\end{array}$ \\
\hline a. Go to shelves $\rightarrow$ Search the book & 5 \\
\hline $\begin{array}{l}\text { b. Get help from Staff } \rightarrow \text { Get class number } \rightarrow \text { Go to shelves } \rightarrow \\
\text { Locate the book }\end{array}$ & 43 \\
\hline $\begin{array}{l}\text { c. Use Catalogue } \rightarrow \text { Note class number } \rightarrow \text { Go to shelves } \rightarrow \\
\text { Locate the book }\end{array}$ & 41 \\
\hline $\begin{array}{l}\text { d. Get help from peers } \rightarrow \text { Use Catalogue } \rightarrow \text { Go to shelves } \rightarrow \\
\text { Locate the book }\end{array}$ & 7 \\
\hline All of above & 2 \\
\hline I don't know & 2 \\
\hline
\end{tabular}

Among the respondents, $43 \%$ of students have selected the option b (Get help from Staff $\rightarrow$ Get class number $\rightarrow$ Go to shelves $\rightarrow$ Locate the book) while $41 \%$ of students have selected the appropriate answer (Use 
Catalogue $\rightarrow$ Note class number $\rightarrow$ Go to shelves $\rightarrow$ Locate the book). The rest of them selected the wrong answers.

\begin{tabular}{|l|c|}
\hline Question 7: \\
\hline $\begin{array}{l}\text { How do you quickly identify the term 'infarction' from the } \\
\text { book }\end{array}$ & $\begin{array}{l}\text { \% of } \\
\text { students }\end{array}$ \\
\hline a. Looking through content page & 2.3 \\
\hline b. Browsing each page of the book & 0.0 \\
\hline c. Browsing index page & 95.5 \\
\hline d. Asking peers who already read the book & 0.0 \\
\hline e. I don't know & 2.3 \\
\hline
\end{tabular}

The appropriate answer (answer c) was selected by $95.5 \%$ of students, while $2.3 \%$ of students selected wrong answer and rest selected 'I don't know'.

\begin{tabular}{|l|c|}
\hline \multicolumn{2}{|l|}{ Question 8: } \\
\hline $\begin{array}{l}\text { Your PBL tutor advised your group to get information on } \\
\text { myocardial infarction on peer-reviewed articles. Where would } \\
\text { you find this information? }\end{array}$ & $\begin{array}{l}\text { \% of } \\
\text { students }\end{array}$ \\
\hline a. Book & 56.8 \\
\hline b. A Blog document & 4.5 \\
\hline c. Journal & 29.5 \\
\hline d. Thesis & 0.0 \\
\hline e. Magazine & 0.0 \\
\hline f. I don't know & 9.1 \\
\hline
\end{tabular}

Most of the respondents (56.8\%) have selected the option a (Book); however, the appropriate answer is option c (Journal). 9.1\% of students have admitted that they do not know.

\begin{tabular}{|l|c|}
\hline Question 9: \\
\hline $\begin{array}{l}\text { Boolean operators are used to combine search terms and show } \\
\text { their relationships. }\end{array}$ & $\begin{array}{l}\text { \% of } \\
\text { students }\end{array}$ \\
\hline a. True & 13.6 \\
\hline b. False & 9.1 \\
\hline c. I don't know & 77.3 \\
\hline
\end{tabular}

Most of the students (77.35) have reported that they do not know about Boolean operators. However, only $13.6 \%$ of students have selected appropriate answer (option a). 


\begin{tabular}{|l|l|}
\hline Question 10: \\
\hline $\begin{array}{l}\text { In order to search infarction on the web, which one of the } \\
\text { following site is best }\end{array}$ & $\begin{array}{l}\% \text { of } \\
\text { students }\end{array}$ \\
\hline a. Google play & 0.0 \\
\hline b. Google Doc & 4.5 \\
\hline c. Google.com & 56.8 \\
\hline d. Google plus & 2.3 \\
\hline e. Google.lk & 25.0 \\
\hline f. I don't know & 11.4 \\
\hline
\end{tabular}

The appropriate answer (Google.com) was selected only by $56.8 \%$ of students, while $25 \%$ of students selected option e (Google.lk) and $11.4 \%$ of students have admitted that they do not know.

\begin{tabular}{|l|c|}
\hline Question 11: \\
\hline $\begin{array}{l}\text { Information from Wikipedia can be used as reference for } \\
\text { research work. }\end{array}$ & $\begin{array}{l}\text { \% of } \\
\text { students }\end{array}$ \\
\hline a. True & 18.2 \\
\hline b. False & 75.0 \\
\hline c. I don't know & 6.8 \\
\hline
\end{tabular}

The appropriate answer (answer b) was selected by $75 \%$ of students, while $18.2 \%$ selected the wrong answer.

\begin{tabular}{|l|l|}
\hline \multicolumn{2}{|l|}{ Question 12: } \\
\hline $\begin{array}{l}\text { Among the characteristics that are used to evaluate the quality of } \\
\text { an internet site one finds: }\end{array}$ & $\begin{array}{l}\text { \% of } \\
\text { students }\end{array}$ \\
\hline a. The date of publication is provided & 4.5 \\
\hline b. The author is known in the field & 4.5 \\
\hline c. Responsibility for the site is clearly indicated & 11.4 \\
\hline d. All of the above & 61.4 \\
\hline e. None of the above & 2.3 \\
\hline f. I don't know & 15.9 \\
\hline
\end{tabular}

The appropriate answer (answer d) was selected by $61.4 \%$ of students, while $15.9 \%$ of students admitted that they did not know the answer. $20.4 \%$ of students have selected correct individual statements but failed to identify that all three are correct. 
The results clearly reflect the strengths and weaknesses of students in locating skills. Even though most of the students do not know the proper route to access the books in an established library, about $41 \%$ of students selected the appropriate route among the answer. However, the faculty library has not yet developed any classic or modern cataloguing system, because of the lack of space and facilities.

Furthermore, most of the students have a good idea of finding the information in the book, selecting suitable search engine and the evaluation of websites. However, later two needs improvement to uplift the knowledge of all the students. It is clearly visible that the students do not have knowledge to differentiate between textbooks and scholarly article. This may be because the students in their undergraduate level mostly depend on books rather than journals. Moreover, students did not have the idea of Boolean operators, which are very vital in defining search queries in search engines. Most of the students reported that they do not know about Boolean operators.

These seven questions were given score to analyse the overall score of the locating skill. As such, the overall average of score for locating skill is $47 \%$ out of hundred. The minimum score is approximately $14 \%$ and the maximum score is approximately $85 \%$. The overall average on locating skill for male and female are $54.9 \%$ and $51.4 \%$, but there is no statistical significance between male and female ( $>0.05)$. According to the marks distribution (Figure 2), 55\% of students fall under the 'Satisfactory level' (i.e. $41-60 \%$ of marks). There is no association between gender and level satisfaction at 95\% confident interval (chi ssqure-3.073, df-4, p-0.546).

\section{Comprehension and Creating Skills}

The five multiple choice questions from numbers 13 to 17 were designed to test different skills related to comprehension and creating skills. Among them first two are corresponding to comprehension skill while the rests of them are related to creating skills. 


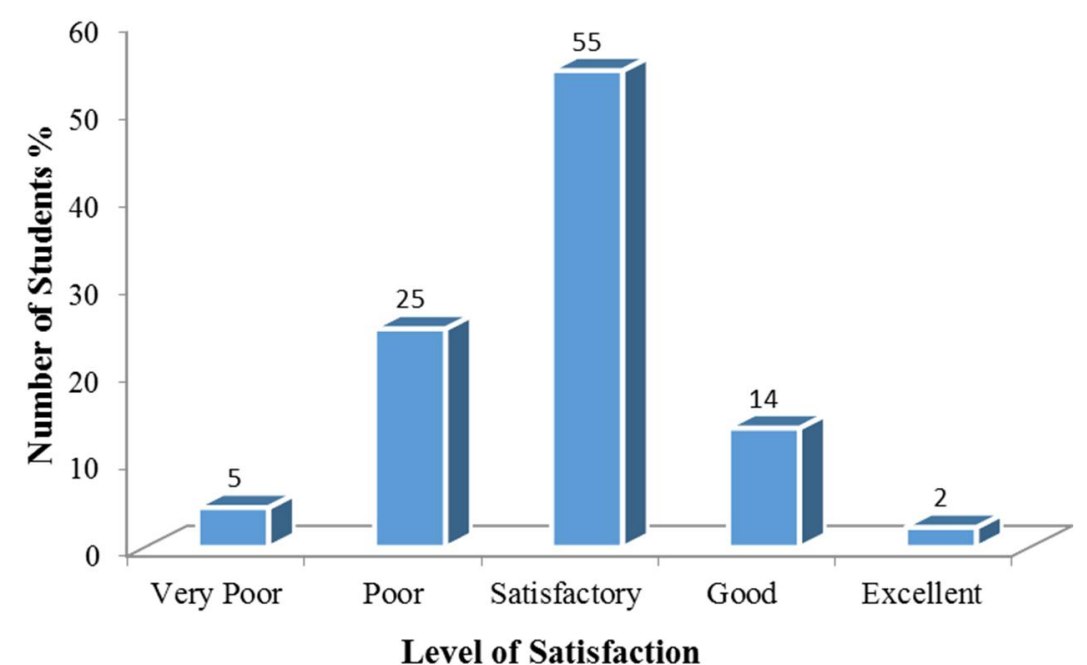

Figure 2: Distribution of locating skill marks

The questions numbers 13 to 16 have been designed according to the performance indicators under the information literacy standard numbers 2 and 3 of the ACRL (2000). The questions corresponding to the effective reading, note making and taking citation have been related to the last performance indicator under the standard two (the information literate student extracts, records, and manages the information and its sources) and first performance indicator under standard three (The information literate student summarizes the main ideas to be extracted from the information gathered).

The question number 16 which is related to synthesizing are related to the performance indicator of the standard three (The information literate student synthesizes main ideas to construct new concepts). The question number 17 is related to last ACRL (2000) standard that is the information literate student understands many of the economic, legal, and social issues surrounding the use of information and accesses and uses information ethically and legally. 


\begin{tabular}{|l|c|}
\hline Question 13: \\
\hline $\begin{array}{l}\text { You have selected a book to get information about Myocardial } \\
\text { infarction. Before reading the text, it is better to skim the text. } \\
\text { What is the purpose of skimming? }\end{array}$ & $\begin{array}{c}\text { \% of } \\
\text { students }\end{array}$ \\
\hline a. To find particular piece of information from the text & 11.4 \\
\hline b. To find particular key word from the text & 9.1 \\
\hline c. To understand the main idea of text & 45.5 \\
\hline d. To familiarise with various words of text & 9.1 \\
\hline e. I don't know & 25.0 \\
\hline
\end{tabular}

The results show that only $45.5 \%$ (option c) of respondents have the idea about skimming while the rests of them do not have. Among them 25\% students reported that they do not know.

\begin{tabular}{|l|c|}
\hline \multicolumn{2}{|l|}{ Question 14: } \\
\hline $\begin{array}{l}\text { In the review session, it is better to use any note taking method. } \\
\text { Which of the following is a note taking method? }\end{array}$ & $\begin{array}{l}\text { \% of } \\
\text { students }\end{array}$ \\
\hline a. KWL+ Method & 2.3 \\
\hline b. REAP Method & 2.3 \\
\hline c. Cornell Method & 2.3 \\
\hline d. Mind Mapping & 22.7 \\
\hline e. I don't know & 70.5 \\
\hline
\end{tabular}

The appropriate answer is 'Cornell Method' which was selected only $2 \%$ of respondents and $70.5 \%$ of respondents reported that they do not know about note taking method.

\begin{tabular}{|c|c|}
\hline \multicolumn{2}{|l|}{ Question 15: } \\
\hline $\begin{array}{l}\text { When search the infarction on web, the following was obtained } \\
\text { from a web. }\end{array}$ & $\begin{array}{l}\% \text { of } \\
\text { students }\end{array}$ \\
\hline Hong Kong Med J. 2013 Aug; 19(4):354-6. doi: 10.12809/hkmi133936. & \\
\hline Mad honey poisoning mimicking acute myocardial infarction. & \\
\hline Chen SP Lam YH, Na VCh, Lau FL, Sze YC, Chan WT, Mak TW. & \\
\hline Toxicology Reference Laboratory, Princess Margaret Hospital, Laichikok, Hong Kong. & \\
\hline PMID: 23918513 [PubMed - in process] Free full text & \\
\hline What is the citation above for & \\
\hline a. Book & 2.3 \\
\hline b. A Blog document & 9.1 \\
\hline c. Journal & 45.5 \\
\hline
\end{tabular}




\begin{tabular}{|c|c|}
\hline d. Thesis & 4.5 \\
\hline e. Magazine & 2.3 \\
\hline f. I don't know & 36.4 \\
\hline
\end{tabular}

According to the results about $55 \%$ of students failed to identify the appropriate answer (Journal) and among them 36.4\% of students reported that they do not have idea about this citation.

\begin{tabular}{|l|l|}
\hline Question 16: \\
\hline At the end of class you are required to prepare a review of & $\%$ of \\
literature. Using the list $1-10$ below, identify the one correct & students \\
answer that demonstrates the basic sequence for the general & \\
format of a review of literature. & \\
1. Organize and illustrate the conclusion(s) & \\
2. Summarize individual studies or articles & \\
3. Define the topic or scope of the review & \\
4. List references & 0.0 \\
5. Point out overall trends or patterns & 4.5 \\
\hline a. $5,2,1,4,3$ & 34.1 \\
\hline b. 5,4,3,2,1 & 18.2 \\
\hline c. $3,5,2,1,4$ & 43.2 \\
\hline d. $3,2,5,1,4$ & \\
\hline e. I don't know & \\
\hline
\end{tabular}

Most of the respondents (43.2\%) reported that they do not know the chronological succession of the literature review, $18.2 \%$ of respondents have selected the appropriate answer (option d).

\begin{tabular}{|l|c|}
\hline Question 17: \\
\hline $\begin{array}{l}\text { Below is a passage taken from an article by Lapetina and } \\
\text { Armstrong (2002): }\end{array}$ & $\begin{array}{l}\% \text { of } \\
\text { Some errors in cosmetic surgery could be prevented if patients } \\
\text { sere made aware of their physician's level of training. }\end{array}$ \\
$\begin{array}{l}\text { Which of the following represent a plagiarized version of the } \\
\text { above sentence? Check all that apply: }\end{array}$ & \\
\hline $\begin{array}{l}\text { a. If patients are told about their physician's level of training, } \\
\text { there will be fewer errors in cosmetic surgery (Lapetina \& } \\
\text { Armstrong, 2002). }\end{array}$ & \\
\hline $\begin{array}{l}\text { b. Given the elective nature of cosmetic surgery procedures and } \\
\text { the frequency of post-operative complications, it has been } \\
\text { recommended that patients should be "made aware of their }\end{array}$ & 15.9 \\
\hline
\end{tabular}




\begin{tabular}{|c|c|}
\hline $\begin{array}{l}\text { physician's level of training" (Lapetina \& Armstrong, 2002, } \\
\text { p.36). }\end{array}$ & \\
\hline $\begin{array}{l}\text { c. Because there are many medical errors in cosmetic surgery, } \\
\text { patients should be made aware of their physician's level of } \\
\text { training. }\end{array}$ & 22.7 \\
\hline $\begin{array}{l}\text { d. Some errors in cosmetic surgery might be averted through } \\
\text { consumers' awareness of a physician's level of education } \\
\text { (Lapetina \& Armstrong, 2002). }\end{array}$ & 9.1 \\
\hline e. I don't know & 50.0 \\
\hline
\end{tabular}

Half of the respondents reported that they do not know about plagiarism. The appropriate answer (option c) was selected by $22.7 \%$ of respondents.

The overall results show that about half of the students do not have the idea of effective reading and most of the students do not have the knowledge on note taking method. These two comprehension skills are very vital for effective learning both in traditional lecture based learning and Problem Based Learning.

About half of the students have identified the citation of a given document as appeared on the website. Most of the students have failed to identify the proper sequence in an academic way of writing. The results also show that students do not have a clear idea of plagiarism and its avoidance.

When these five questions were graded by the score, the overall average for comprehension and creating skill was $26.36 \%$ out of hundred. The lowest score is $0 \%$ and the highest score is $80 \%$. When analysing the marks distribution (Figure 3), most of the students fall under the 'Very Poor' level. The overall average for comprehension and creating skill for male and female are $24.2 \%$ and $28 \%$ respectively, but there is no statistical significance between male and female. There is no association between gender and level satisfaction at 95\% confident interval (chi ssqure-1.383, df$3, \mathrm{p}-0.709)$. 


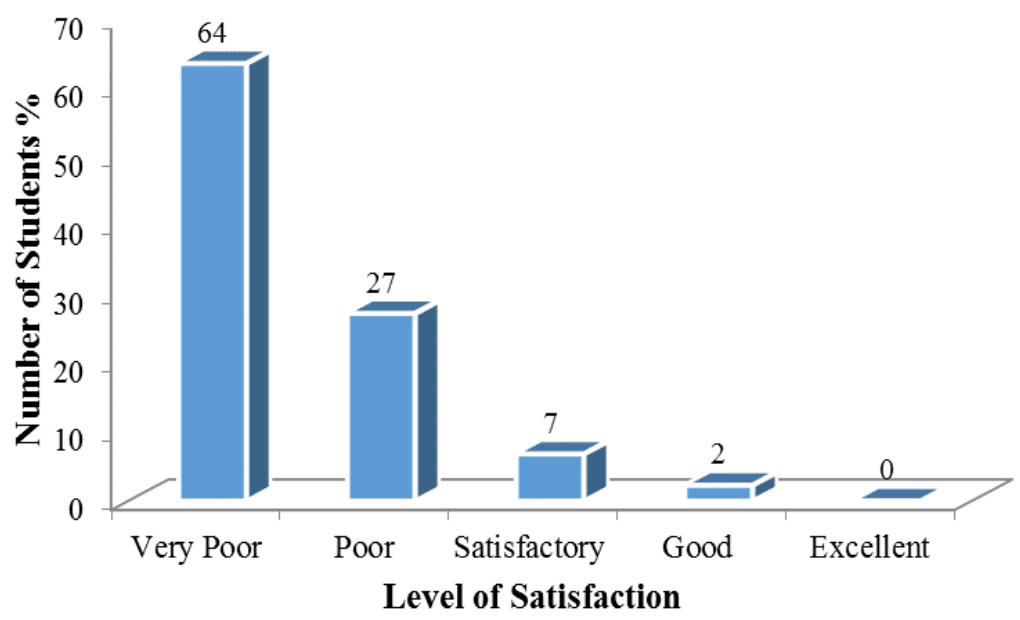

Figure 3: Distribution of Comprehension and Creating skill marks

\section{Presenting Skills}

The last two questions were designed to test the presenting skills. The overall average score for the presenting skill is $51.14 \%$. In fact these questions have been developed based on the performance indicator that is the information literate student communicates the product or performance effectively to others under the ACRL (2000) standard 4.

\begin{tabular}{|c|c|}
\hline Question 18: & \\
\hline $\begin{array}{l}\text { In the wrap-up session, your group is required to prepare a } \\
\text { PowerPoint presentation for next PBL session. There are } \\
\text { important guidelines that you should consider when using the } \\
\text { PowerPoint program. } \\
\text { Choose the one answer that would NOT contribute to the } \\
\text { effectiveness of your presentation. }\end{array}$ & $\begin{array}{l}\% \text { of } \\
\text { students }\end{array}$ \\
\hline a. Use a minimum number of words; avoid complete sentences & 15.9 \\
\hline $\begin{array}{l}\text { b. Use as many visual and auditory aids as possible to keep } \\
\text { your audience interested }\end{array}$ & 13.6 \\
\hline $\begin{array}{l}\text { c. Make sure that the contrast between the colours of the text } \\
\text { and background are pleasing to the eye, and that the text is } \\
\text { easy to read }\end{array}$ & 4.5 \\
\hline d. Text should usually be displayed in outline form & 47.7 \\
\hline e. I don't know & 18.2 \\
\hline
\end{tabular}


The appropriate answer (answer d) was selected by $47.7 \%$ of respondents while others failed to identify the answer. Among them, $18.2 \%$ of respondents have admitted that they do not know.

\begin{tabular}{|l|c|}
\hline Question 19: \\
\hline What are the 3Ps for an effective presentation & \% of students \\
\hline a. Plan, prove, prepare & 4.5 \\
\hline b. Plan, prepare, prove & 20.5 \\
\hline c. Prepare, practice, provide & 4.5 \\
\hline d. Plan, prepare, perform & 52.3 \\
\hline e. I don't know & 18.2 \\
\hline
\end{tabular}

The appropriate answer (option d) was selected by $52.3 \%$ of respondents while others failed to identify the right answer.

The overall results of presenting skill reveal that nearly half of the students have a clear idea in aspects that leads to an effective presentation. When giving a score to presenting skill, the average score of students was about $51 \%$. The distribution of marks (Figure 4) shows that most of the students fall within the 'Satisfactory' level. The overall average for male and female are $44.7 \%$ and $56 \%$ respectively, but there is no statistical significance ( $>0.05$ ). As in previous cases, here too there is no association between gender and level of satisfaction at $95 \%$ confident interval (Chi square-1.552, df-2, p-0.46).

The comprehensive view of the results gives an overall performance or level of information skill of medical undergraduates. As such, the overall average score is $39 \%$ and the lowest average score of the students $13.57 \%$ and highest average score is $65.71 \%$. About $43 \%$ of students fall within the 'Satisfactory level' (41-60\%) according to the marks distribution of overall performance (Figure 5). 


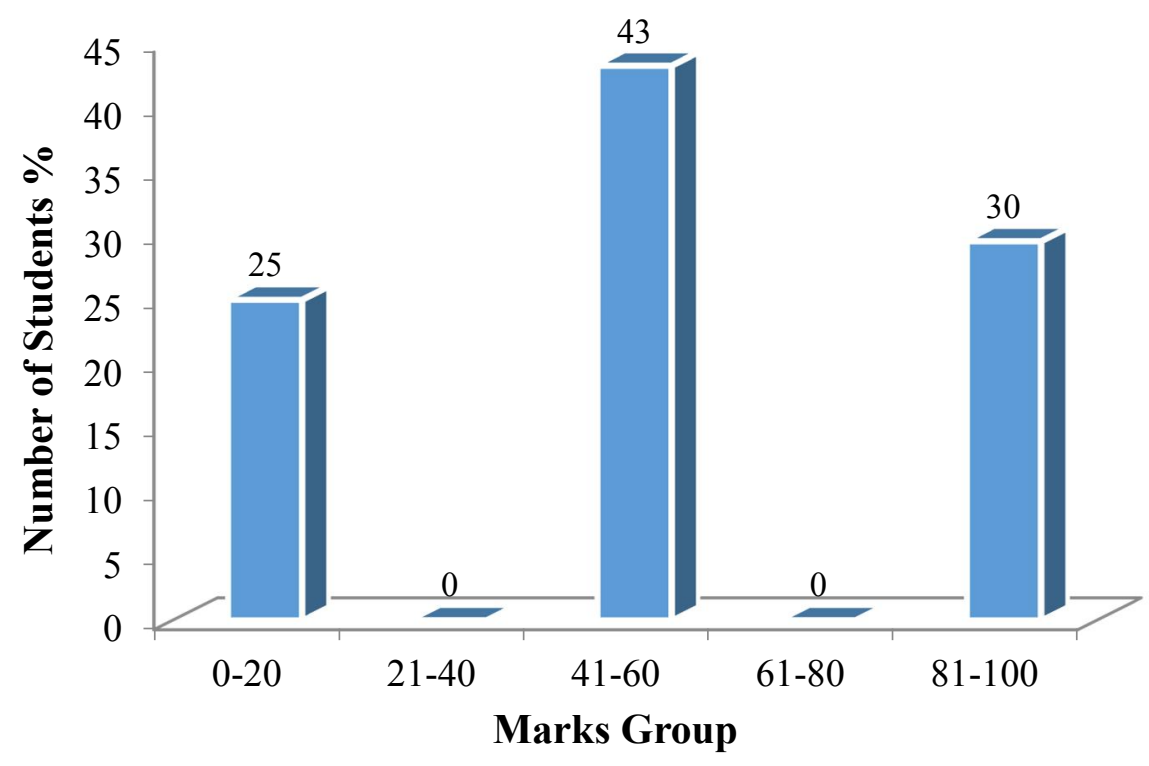

Figure 4: Distribution of presenting skill marks

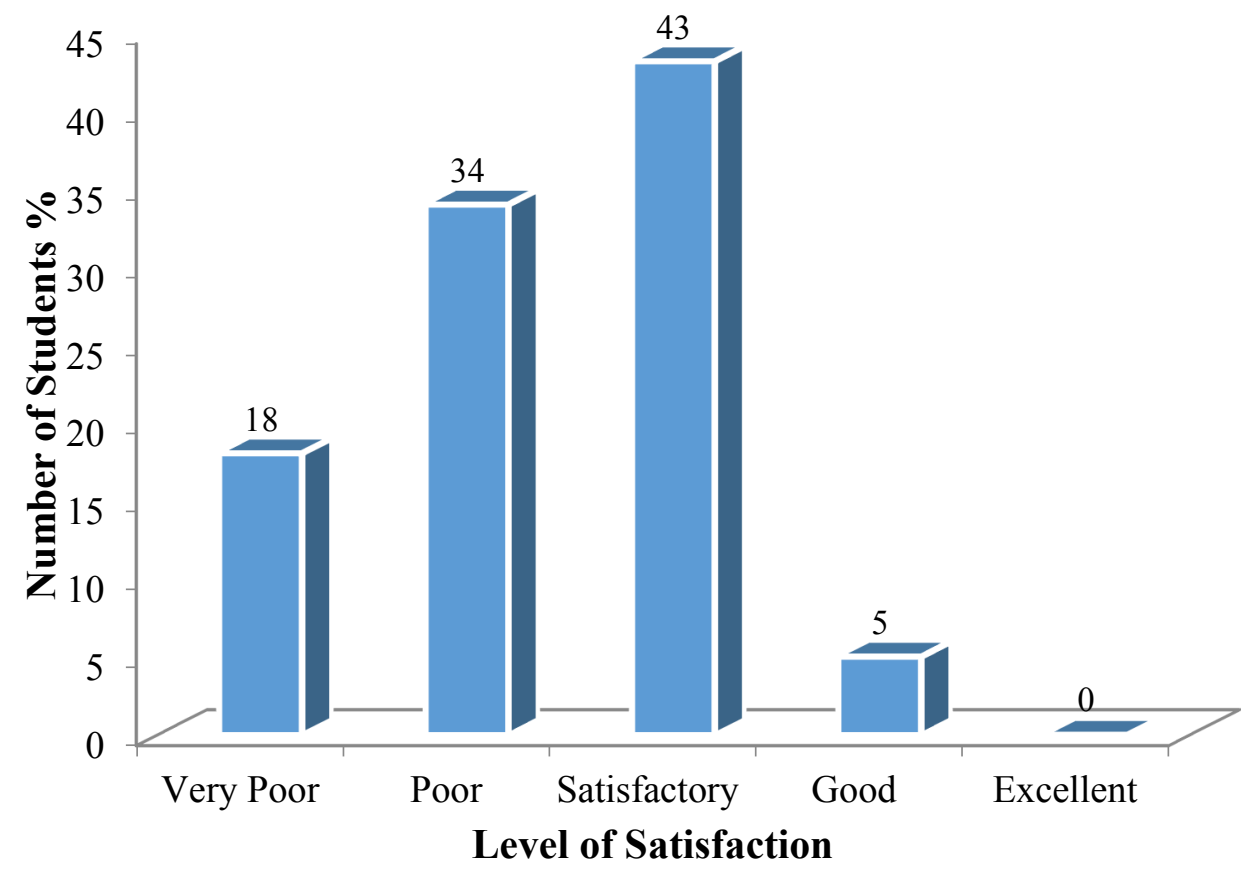

Figure 5: Distribution of overall IL marks among the respondents 


\section{Conclusion}

This study analyzed the level of information literacy of medical undergraduates who are engaged in Problem Based Learning. The IL skills have been listed under four categories which are analytical skills, locating skills, comprehension and creating skills and presentation skills. The analytical skills are more important in first few steps in PBL in order to analyze the triggers/problems to identify the learning needs or the gap in knowledge to solve the given problem. Under the analytical skill, identification of keywords, knowledge on concept map and 5WH techniques, identification of suitable information resources were tested. Majority of the students were weak in the above skills except in the identification of keywords. And, more than fifty percentage of students fall under poor and very poor level in overall performance for analytical skills.

In the locating skills, although $55 \%$ of students fall under the satisfactory level (i.e. $41-60 \%$ of marks), when analyzing case by case that the majority of the students did not have enough knowledge on accessing library resources, use of different sources of information, techniques for online searching, appropriate search engines and website evaluation except the knowledge on the use of the parts of a book. However, in the comprehension and creating skills, only $9 \%$ of students were in satisfactory and good level, rest of them were in poor and very poor level. It was observed students do not have enough knowledge on reading technique, note taking methods, identifying citation, organizing report and plagiarism. Comparing to previous three skills, majority of the students have good knowledge on the knowledge on presentation related techniques. $43 \%$ of them were in satisfactory level while $30 \%$ of them in excellent level.

In the overall information literacy level only $43 \%$ of students are in satisfactory level, while majority of the students $(52 \%)$ fall under poor and very poor level, while $5 \%$ of students in good level. The conclusion clearly reflect that the information literacy level of the medical undergraduates of Faculty of Health-Care Sciences are not up to the standard. Since the IL is paramount to PBL, it is recommended to introduce the IL programme in the medical education. It will not only make ease the problem based learning process but also help to students' research project. 


\section{Acknowledgement}

I am extremely indebted to my teacher, Mr. P.G. Premadasa, Senior Lecturer, NILIS, University of Colombo, for guiding my master's degree research. His knowledge and experience in the field of information literacy had tremendously helped me crafting the research work, especially in literature review.

\section{References}

ACRL (2000). Information Literacy Competency Standards for Higher Education. Association of College and Research Libraries._American Library Association. Retrieved from http://www.ala.org/acrl/standards/informationliteracycompetency (05-05-2013)

ALA. (1989). Presidential committee on information literacy: Final report. American Library Association. Retrieved from http://www.ala.org/ala/acrl/ acrlpubs/ whitepapers/presidential.htm (06-05-2013).

Andretta, S. (2005).From prescribed reading to the excitement or the burden of choice, Aslib Proceedings, 57 (2), 181 - 190. DOI: http://dx.doi.org/10.1108/00012530510589146

Bartlett, E. J., Kotrlik, J.W., \& Higgins, C.C. (2001).Organizational Research: Determining Appropriate Sample Size in Survey Research. Information Technology, Learning, and Performance Journal, 19 (1), 43-50.

Bundy, A. (2004). Australian and New Zealand Information Literacy Framework: principles, standards and practice. Australian and New Zealand Institute for Information Literacy. Retrieved from http://www.anziil.org/index.htm (10-08-2013)

Campbell, D. (2009). Student Learning in Library Research Instruction for Critical Writing, Reading and Research I \& II. Assessment Report for Academic Year 2008-2009. Millikin University. Retrieved from http://www.millikin.edu/staley/ services/instruction/documents /0809cwrrreport.pdf (12-01-2014)

Dodd, L. (2007). The impact of problem-based learning on the information behavior and literacy of veterinary medicine students at University College Dublin, The Journal of Academic Librarianship, 33 (2), 206216. 
Dodd, L. (2010). Collaboration and Sustainability: Integrating Information Literacy into Enquiry and Problem-based Learning Initiatives in UCD. In Barrett, T., Cashman, D. (Eds) A Practitioners' Guide to Enquiry and Problem-based Learning. Dublin: UCD Teaching and Learning.

Haraldstad, A.M. (2002). Information Literacy - Curriculum Integration with Medical School's Syllabus. Liber quarterly, 12. 192-198. Retrieved from https://liber.library.uu.nl/index.php/lq/article/download /URN\%3ANBN\%3ANL\%3AUI\%3A10-1-113296/7718 (08-052013).

Ivanitskaya, L. (2006). Competencies of Information Age Students: Results from the Interactive Online Research Readiness Self-Assessment (RRSA). J Med Internet Res, 8 (2).

Jungwirth, B., \& Bertram, B. (2002). Information overload: Threat or opportunity? Journal of Adolescent \& Adult Literacy 45(5). Retrieved from people.lis.illinois.edu/ chip/ pubs/03LIA/13-003.pdf (11-122013).

Laurillard, D. (n.d.). The Changing University. Retrieved March 18, 2016, from http://itforum.coe.uga.edu/paper13/paper13.html

Mittermeyer, D., \& Quirion, D. (2003). Information Literacy: Study of Incoming First-Year Undergraduates in Quebec. Conference of Rectors and Principals of Québec Universities. Retrieved from crepuq.qc.ca/documents/bibl /formation/studies_Ang.pdf (16-082013)

Oker-Blom, T. (1998) Integration of Information Skills in Problem Based Curricula, 64th IFLA General Conference, August 16-21, 1998, Amsterdam, 1-8.

Peters, K., Jones, R., \& Matthews, D. (2007). Training for Independent Learning. Library and Information Update, 5(1), 4-8.

Santharooban, S and Pemadasa, P.G. (2015). Development of an Information Literacy Model for Problem Based Learning. Annals of Library and Information Studies, 62 (3), pp138-144. URL: http://op.niscair.res.in/index.php/ALIS/article/download/ 8472/444.

Schilling, K., Ginn, D.S., \& Mickelson, P. (1995). Integration of information seeking skills and activities into a problem based curriculum. Bull Med Libr Assoc, 83 (2),176-183.

Seneviratne, T.M., \& Wickramasinghe, V.M. (2010). Information Literacy Skills of Undergraduates of University of Moratuwa. Journal of the University Librarians Association of Sri Lanka. 14 (1), 15-30. 
Staley, S.M., Branch, N.A., \& Hewitt, T.L. (2010). Standardised library instruction assessment: an institution-specific approach. Information research, 15 (3). Retrieved from http://informationr.net/ir/153/paper436.html (11-12-2013).

Thirion, P., \& Pochet, B. (2009). Information Literacy in students entering higher education in the French speaking community of Belgium: lessons learned from an evaluation. IFLA Journal, 35(2), 152-170. doi:10.1177/0340035209105671

Trail, M.A., Gutierrez, C., \& Lechner, D. (2006). Reconsidering a Traditional Instruction Technique: Reassessing the Print Workbook. The Journal of Academic Librarianship, 32 (6), 632-640.

WCPT (2003). European Physiotherapy Benchmark Statement. European Region of the World Confederation for Physical Therapy (WCPT). Barcelona, Spain. 42. Retrieved from http://www.physioeurope.org/index.php?action $=80(01-12-2013)$ 